\title{
Exploración de la interacción entre la región 5'UTR del Sugarcane Mosaic Virus (SCMV) y proteínas del hospedero maíz
}

\author{
Exploration of the interaction between the 5'UTR region of Sugarcane Mosaic Virus \\ (SCMV) and host maize proteins
}

\section{Exploração da interação entre a região 5'UTR do Sugarcane Mosaic Virus (SCMV) e proteínas do hospedeiro milho}

\author{
Giovanni Chaves-Bedoya ${ }^{1}$
}

Forma de citar: G. Chaves-Bedoya, "Exploración de la interacción entre la región 5'UTR del Sugarcane Mosaic Virus (SCMV) y proteínas del hospedero maíz", Respuestas, vol. 22, no. 1, pp. 103-111, 2017.

Recibido:

Agosto 30 de 2016

Aceptado:

Diciembre 1 de 2016

\section{Resumen}

Antecedentes: El virus del mosaico de la caña de azúcar, SCMV (Potyviridae) es un miembro de la gran familia de virus de ARN de cadena positiva, sin una estructura CAP en su extremo 5'no traducido (5'UTR), pero con una proteína viral unida al genoma (VPg) y una cola poli A en su extremo 3'UTR. Se ha sugerido que proteínas del hospedero hacen un puente entre las regiones no traducidas virales $5^{\prime}$ y $3^{\prime}$ para potenciar la traducción viral. Dado que las regiones no traducidas presentes en los genomas virales contienen elementos involucrados en la regulación de su ciclo replicativo, es importante analizar la interacción entre estas regiones y las proteínas virales o del hospedero para inferir su función. Objetivo: Determinar si existen proteínas del hospedero maíz que pudieran estar interactuando con la región 5'UTR de SCMV. Metodología: La región 5'UTR de SCMV se amplificó por PCR incluyendo la secuencia del promotor T7 en la secuencia del oligo 5' UTR y se generaron sus transcritos marcados radiactivamente. Los transcritos marcados fueron entrecruzados con extractos proteicos de hojas de maíz sanas e infectadas. Resultados: Los resultados sugieren la presencia de una proteína putativa de interacción del hospedante maíz de aproximadamente $53 \mathrm{kDa}$, con la región 5 'UTR de SCMV. Conclusión: Los ensayos de entrecruzamiento, especificidad y estabilidad de los complejos ARN-proteína sugieren que en el hospedante maíz existe al menos una proteína que interactúa con la región 5' UTR de SCMV.

Palabras Clave: Complejo ARN-proteína, entrecruzamiento UV, fracción proteica, Potyvirus, VPg.
${ }^{1}$ Doctorado en Biotecnología Vegetal gchavesb@ufps.edu.co Orcid: 0000-0003-1013-614X Grupo de Investigación PLANTAE, Facultad de Ciencias Básicas Universidad Francisco de Paula Santander Cúcuta-Colombia

\begin{abstract}
Background: Sugarcane mosaic virus is a member of the great family of positive sense RNA viruses, without a CAP structure in its 5'UTR end, but with a viral protein attached to the genome (VPg) and a poli A tail in its 3'UTR end. It has been suggested that some host proteins make a bridge between the untranslated 5' and 3 ' regions (UTRs) to enhance the canonical and/or non-canonical virus translation. Since the UTR regions present in the viral genomes have some elements involved in the regulation of their replicative cycle, it is important to analyze the interaction that may occur between these regions and the viral or host proteins to infer regarding its function. Objective: To identify proteins of
\end{abstract}


No. 1

Enero - Junio 2017 ISSN 0122-820X

E-ISSN 2422-5053 PP: 103-111

the host maize that could be interacting with the 5'UTR region of SCMV. Methodology: 5'UTR region of SCMV was amplified by PCR including the sequence of the T7 promoter in the 5 'oligo sequence. The transcripts were radioactively labeled. Labeled transcripts were crosslinked with proteins extracts from healthy and infected maize leaves. Results: The results suggest the presence of a $53 \mathrm{kDa}$ putative protein interacting with the 5 'UTR region of SCMV. Conclusion: Crosslinking essays, specificity and the stability of the RNA-protein complex suggest that in maize host there is at least one protein that interacts with the 5'UTR region of SCMV.

Keywords: RNA-Protein complex, UV crosslinking, protein fraction, Potyvirus, VPg

\section{Resumo}

Antecedentes: O vírus do mosaico da cana de açúcar (SCMV) da Família Potyviridae é um membro da grande família de vírus de ARN de cadeia positiva, sem uma estrutura CAP em seu extremo $5^{\prime}$ não traduzido (5 'UTR), mas com uma proteína viral unida ao genoma (VPg) e uma cola poli A em seu extremo 3'UTR. Tem-se sugerido que proteínas do hospedeiro fazem uma ponte entre as regiões não traduzidas virales 5'e 3' para potenciar a tradução viral. Devido que as regiões não traduzidas presentes nos genomas virais contém elementos involucrados na regulação de seu ciclo replicativo, é importante analisar a interação entre estas regiões e as proteínas virales $\mathrm{O}$ do hospedeiro para inferir sua função. Objetivo: Determinar se existem proteínas hospedeiras milho que puderam estar interatuando com a região 5'UTR de SCMV. Metodologia: A região 5'UTR de SCMV se amplificou por PCR incluindo a sequência do promotor T7 na sequência do oligo 5' UTR e se geraram seus transcritos marcados radiativamente. Os transcritos marcados foram entrecruzados com extratos proteicos de folhas de milho saudáveis e infetadas. Resultados: Os resultados sugerem a presença de uma proteína putativa de interação do hospedeiro milho de aproximadamente $53 \mathrm{kDa}$, com a região 5'UTR de SCMV. Conclusão: Os ensaios de entrecruzamento, especificidade e estabilidade dos complexos ARN-proteína sugerem que no hospedeiro milho existe pelo menos uma proteína que interatua com a região 5' UTR de SCMV.

Palavras-chave: complexo ARN-proteína, entrecruzamento UV, fracção proteica, Potyvirus, VPg,

\section{Introducción}

El virus del mosaico de la caña de azucar (SCMV), es un miembro del grupo de los potyvirus, dentro de la familia Potyviridae, y puede infectar varios cultivos, incluyendo caña de azúcar, sorgo y maíz, causando clorosis y retraso en el crecimiento [1].

\section{Los virus como SCMV codifican relativamente} un numero bajo de genes con respecto a sus hospederos. Por ejemplo, las células de hospedantes vegetales codifican miles de genes, por lo que la mayoría de pasos en la infección viral involucra interacciones entre relativamente pocos componentes virales y muchos factores del hospedero. Los factores del hospedero juegan papeles importantes en la mayoría de pasos de la infección viral, y la identificación de tales factores y sus contribuciones ha sido reconocido como un importante objetivo de investigación [2].

Los genomas vegetales codifican proteínas de unión a ARN, las cuales se piensa que se unen a sitios específicos de los ARN mensajeros afectando la fisiología de las plantas. Sin embargo, la función de estas proteínas aun no es muy clara en términos 
de cómo las interacciones entre el ARN viral y las proteínas de unión al ARN se regulan de manera específica, o cómo estas proteínas influyen en el ARN viral [3].

En el caso de los Potyvirus como el virus del mosaico de la caña de azúcar (SCMV), funciones como la replicación y movimiento sistémico requieren de la interacción de factores del hospedero con proteínas virales y ARN [4]. Aunque se conoce mucho respecto a la función individual de las proteínas de los potyvirus y la estructura del ARN en la replicación viral y el movimiento, [5], [6] poco se conoce acerca de la identidad y función de los factores del hospedero que son requeridos para la infección potyviral en plantas [7].

De manera similar a los ARNm celulares, los ARN virales de cadena positiva tienen regiones codificantes y regiones no traducibles (UTRs). El ARN de los potyvirus, tiene una proteína viral unida al extremo 5'UTR y una cola poli(A) en el extremo 3'UTR. En contraste a los ARNm celulares, el extremo 5'de los ARN virales puede tomar una de diferentes formas: un grupo fosfato, una proteína "cap", o un polipéptido codificado por el virus llamado VPg ("Viral protein genome-linked"), unida covalentemente al primer nucleótido de ARN [8].

Los virus de ARN de cadena positiva han evolucionado diferentes maneras para utilizar los recursos de las células huésped. Sin embargo, a pesar de los diversos juegos de factores del hospedero que son reclutados por diferentes virus, los estudios funcionales sugieren que las diferentes proteínas de los hospederos podrían proporcionar funciones similares durante la replicación del ARN viral [9].

La interacción entre proteínas o de proteínas con ARN desempeñan funciones importantes en la mayoría de procesos durante el ciclo de infección viral; por ejemplo, en la formación de los complejos de replicación viral, el ensamble de viriones, el movimiento viral entre células y la transmisión de virus entre plantas por vectores [10]. Como ejemplo, en el caso de los potyvirus, se ha encontrado que la interacción entre el factor de traducción eucariota eIF4E con la proteína viral VPg es necesaria para la infección viral [11], y la resistencia recesiva de la planta al virus se determina por el éxito o no de la interacción entre esta proteína y proteínas virales [12]. En el caso del movimiento viral, los potyvirus no codifican proteínas de movimiento [13], pero se ha determinado que algunas proteínas del virus podrían estar relacionadas con el movimiento potyviral en asociación con proteínas de los hospederos [14]-[16].

Existe información limitada respecto a proteínas del hospedero que interactúen con las regiones no traducidas de potyvirus, sin embargo se ha reportado la interacción de proteínas de hospedero con las regiones 5'UTR y 3'UTR no traducidas del genoma del virus Norwalk [17].

En este trabajo se presentan los resultados exploratorios de la interacción in vitro de la región 5'UTR del virus del mosaico de la caña de azúcar (SCMV) con proteínas del hospedero maíz. El conocimiento y comprensión más detallado de las proteínas de unión al ARN del hospedero requeridas para la replicación viral podrá ayudar en el desarrollo de novedosas estrategias antivirales [18].

\section{Materiales y métodos}

2.1. Extracción de ARN viral. Para la extracción de ARN total, se utilizaron hojas de maíz de plantas que presentaban la sintomatología típica de SCMV utilizando el reactivo TRIzol (Invitrogen), de acuerdo a las instrucciones del fabricante. El ARN cuantificado fue almacenado en alícuotas a una temperatura de $-80^{\circ} \mathrm{C}$ hasta el momento de usar el templado.
Enero - Junio 2017 ISSN 0122-820X E-ISSN 2422-5053 PP: 103-111 


\subsection{Subclonación del extremo 5'del ADN complementario (ADNc) genómico de SCMV}

El segmento desde la posición 1 hasta la posición 892 del genoma de SCMV amplificado por RT-PCR se clonó en el vector TOPO de Invitrogen, siguiendo las indicaciones del fabricante. La amplificación específica de la region 5'UTR se realizó empleando el ADNc anterior utilizando un oligo 5'UTR que contenía la secuencia del promotor T7 para facilitar la síntesis de ARN. El fragmento de PCR obtenido de $149 \mathrm{pb}$ fue subsecuentemente clonado en el vector pGEM-T (Promega).

\subsection{Trascripción in vitro de la región $5^{\prime}$} UTR de SCMV. Para la transcripción in vitro se siguió la metodología descrita previamente [19]. La región 5'UTR de SCMV fue amplificada por PCR incluyendo la secuencia del promotor T7 en el oligo $5^{\prime}$. La reaccion de PCR se realizo con 30 ciclos de $94^{\circ} \mathrm{C}$ por 30 segundos, $45^{\circ} \mathrm{C}$ por 30 segundos y $75^{\circ} \mathrm{C}$ x 30 segundos. El producto de PCR fue purificado del gel antes de ser empleado como templado para la sintesis de ARN. La reacción de transcripción in vitro se realizó a $38^{\circ} \mathrm{C}$ por dos horas en un volumen final de 20 $\mu 1$, empleando la RNA polimerasa T7. Luego de la reaccion de transcripción, el molde de ADN remanente se elimino tratando la muestra con $1 \mu$ l DNase RQ1 (Promega) en presencia de inhibidores de ARNasa durante 1 hora a $38^{\circ} \mathrm{C}$. Para la sintesis de los trasncritos de ARN radiomarcados se incluyó $\left[\mathrm{a}^{-32} \mathrm{P}\right] \mathrm{UTP}$ (Dupont).

\subsection{Extracción de proteinas totales de hojas de maiz}

2 gramos de hojas de maíz sana e infectada por separado se lavaron con agua destilada $y$ se maceraron en morteros de porcelana en presencia de tampón fosfato sódico 0,2 M $\mathrm{pH}$ 7.5. El macerado se filtró y se centrifugó a $18.000 \mathrm{rpm}$ a $4^{\circ} \mathrm{C}$ durante 20 minutos. Se colectó el sobrenadante con las fracciones proteicas.

2.5. Ensayos de entrecruzamiento ultravioleta. Para los ensayos de entrecruzamiento inducidos por UV, se incubaron $20 \mu \mathrm{g} / \mu \mathrm{l}$ de extracto proteico de maíz con $1 \times 10^{6}$ c.p.m de $\mathrm{ARN}$ radiomarcado a $0^{\circ} \mathrm{C}$ por 15 minutos expuestos a luz ultravioleta de longitud corta. El ARN no entrecruzado fue cortado con RNasa T1 (25U) y RNasa A (1mg) por 5 minutos y $37^{\circ} \mathrm{C}$. Finalmente, la muestra fue hervida en buffer de carga proteica por $5 \mathrm{~min}$. y analizada en un gel SDS-PAGE. Los geles se secaron y se autoradiografiaron.

2.6. Inmovilización de ARN en perlas de agarosa dihidrazida y ensayos de afinidad de ARN. Este procedimiento se llevó a cabo empleando dihidrazida de ácido adipíco (Sigma) y las metodologías descritas por [20] , [21] con algunas modificaciones. En resumen, $50 \mu \mathrm{g}$ de $\mathrm{ARN}$ sintetizado in vitro se oxidó con periodato de sodio $(10 \mathrm{mM})$ durante 2 horas. El ARN oxidado se precipitó con etanol absoluto y se resuspendió en $100 \mu 1$ de acetato de sodio 0,1 M. El ARN tratado se mezcló con las perlas de dihidrazida de ácido adípico y se colocó en agitacion toda la noche a $4^{\circ} \mathrm{C}$. Las perlas con el ARN inmovilizado se incubaron con el extracto proteico a $4^{\circ} \mathrm{C}$ por 1 hora y las proteinas unidas por afinidad se lavaron con $\mathrm{NaCl}$. Las proteinas recuperadas se corrieron en geles SDS-PAGE.

\section{Resultados y análisis}

\subsection{Verificación de clonación del segmento $5^{\prime}$ de SCMV y transcripción in vitro de la región 5'UTR.}

Con el propósito de verificar que la región correspondiente a la 5'UTR de SCMV estaba siendo amplificada correctamente por PCR y de que el tamaño del transcrito in vitro eran correspondientes, los productos de PCR y de transcripción se corrieron en geles de agarosa. 
En la figura 1, panel A, se puede apreciar un producto amplificado de aproximadamente 150 pares de bases, mientras que en el panel $\mathrm{B}$, se indica lo correspondiente al transcrito de ese segmento. Las imágenes indican que tanto la amplificación por PCR como la transcripción in vitro se sintetizaron de manera adecuada, produciendo tamaños de amplificación esperados.

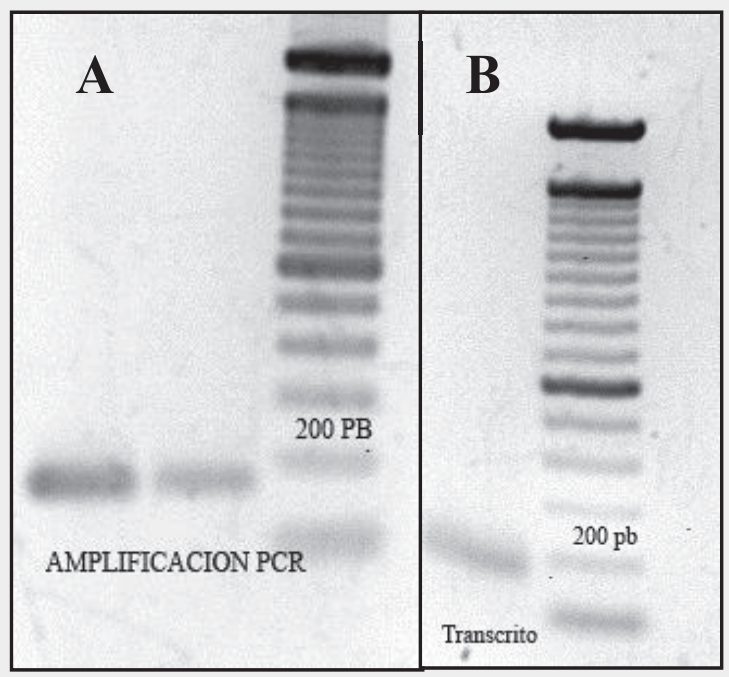

Figura 1. A. RT-PCR de la región 5' UTR de SCMV . B. Transcrito de la región 5'UTR. Tanto los productos de RT-PCR como el transcrito presentan el tamaño esperado Fuente: Autor

\subsection{Interacción de la región $5^{\prime} \mathrm{UTR}$ de SCMV con extractos proteicos de Maíz.}

Para determinar si la región no traducida del extremo 5' del genoma del virus SCMV interactuaba con proteínas del hospedero maíz, los transcritos de ARN marcados radiactivamente con $\mathrm{P}^{32}$ que incluye los nucleótidos 1-149 se incubaron con los extractos proteicos de maíz. Luego de la electroforesis, se encontró al menos un complejo ARN-proteína tanto con los extractos de maíz obtenidos a partir de plantas sanas como de las plantas con expresión clara de síntomas de la virosis (Figura 2). El ensayo de entrecruzamiento se hizo tanto con plantas de maíz sanas como plantas de maíz enfermas. Se puede apreciar que en los dos sistemas se encuentra proteínas de interacción, lo que sugiere que las proteínas con las cuales esta interactuando esta región no son proteínas inducidas por el virus, sino que son proteínas constitutivas de maíz.

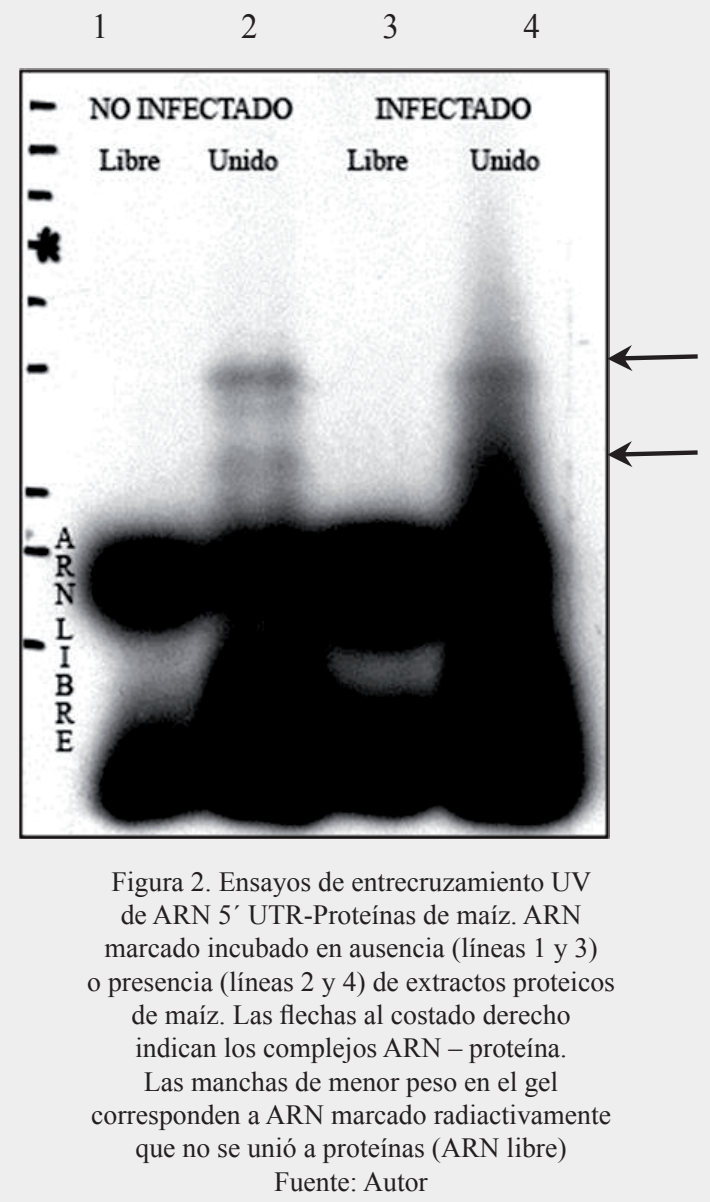

\subsection{Estabilidad de los complejos ARN- Proteína}

Con el propósito de determinar la estabilidad de los complejos ARN-proteína, las muestras se incubaron con diferentes concentraciones de solución salina de cloruro de potasio. Los complejos ARN-proteína formados con el transcrito de 149 nucleótidos de la 5'UTR de SCMV fueron estables ya que aún a concentraciones de $0.6 \mathrm{M}$ de cloruro de potasio no se deshicieron (Figura 3). 
No. 1

Enero - Junio 2017 ISSN 0122-820X E-ISSN 2422-5053 PP: 103-111

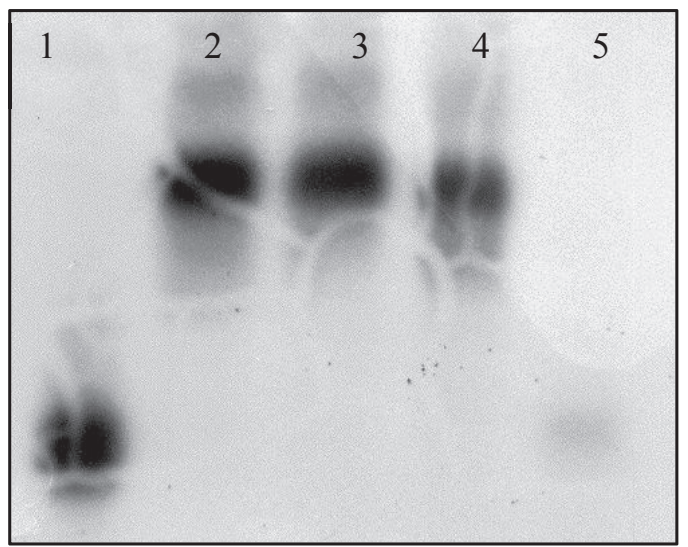

Figura 3. Estabilidad de los complejos 5' UTR. Los Complejos ARN-proteína formados por UV fueron tratados con $\mathrm{KCl} 0.3 \mathrm{M}$ (Línea 3) 0.6M (Línea 4) y proteinasa $\mathrm{K}$ (Línea 5). En la línea $1 \mathrm{ARN}$ marcado libre. Línea $2 \mathrm{ARN}$ unido a proteína sin tratamiento de sal Foto: Autor

Cuando la mezcla se trató con proteinasa $\mathrm{K}$, una serine proteasa, el complejo desaparece (Figura 3, línea 5) por la digestión de la proteína. Cuando no se adicionó proteína al sistema, el ARN se movilizó más rápido porque no se formó ningún complejo (Figura 3, línea 1).

Los resultados de los ensayos de entrecruzamiento y la estabilidad de los complejos ARN-proteína sugieren que en el hospedante maíz existe al menos una proteína que interactúa con la región 5' UTR de SCMV y que esta interacción es estable.

\subsection{Cromatografía de afinidad ARN- Proteína}

Una vez que se encontró evidencia de la presencia de por lo menos una proteína del hospedero maíz que formaba complejos con el trascrito de 149 nucleótidos de la región 5'UTR de SCMV, se realizó el ensayo de cromatografía de afinidad empleando dihidrazida de ácido adípico basado en metodologías previamente reportadas [20, 21] con algunas modificaciones. La figura 4 muestra los resultados del gel SDS-PAGE con las proteínas eluídas que estaban unidas por afinidad al transcrito de la región 5'UTR de SCMV. Como control se empleó ARN de transferencia (ARNt), el cual se mezcló con extracto proteico del mismo hospedero maíz. Como se observa en el carril 2 de la figura 4 , con el ARNt no se aprecia el complejo que se formó con los transcritos de la $5^{\prime}$ UTR (Figura 4, carriles 3 y 4), lo que sugiere la especificidad de la interacción de las proteínas del maíz con el transcrito 5'UTR de SCMV.

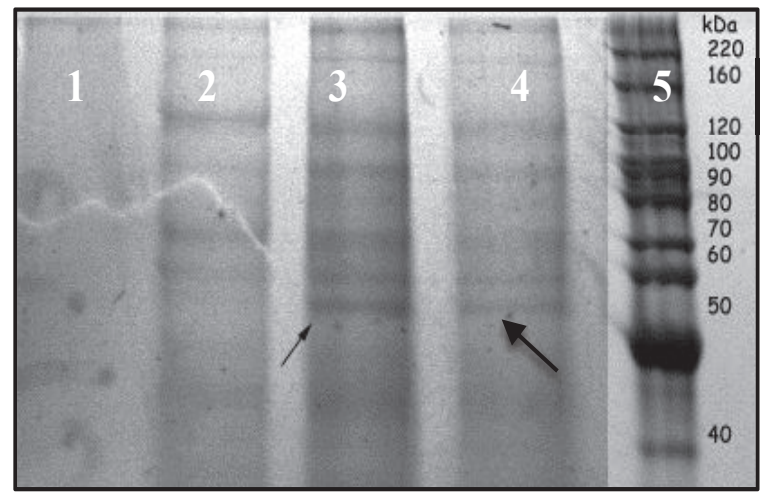

Figura 4. Gel SDS-PAGE con proteínas eluídas. En el carril 1 control sin ARN, carril 2 control con ARNt, carriles 3 y 4 eluídos 1 y 2, carril 5 marcador de peso molecular. En los carriles 3 y 4 se visualiza una banda de aproximadamente $53 \mathrm{kDa}$ que no está presente en el carril 2, en el que se empleó ARNt como control positivo, ni en el carril 1, control en el que no se cargó ARN. En el carril 5 marcador de peso molecular. Fuente: Autor

\section{Discusión de resultados.}

Los genomas de los pequeños virus de ARN de cadena sencilla, sentido positivo, no solamente deben codificar las proteínas virales requeridas para la replicación del genoma viral y la producción de partículas infecciosas, sino que además deben tener estructuras y secuencias de ARN que desempeñan un papel crítico en el ciclo de vida del virus. Los factores celulares del hospedero que interactúan con estos elementos de ARN, desempeñan funciones importantes en todos los aspectos del ciclo de vida del virus [17]. En consecuencia, la manipulación de estas interacciones o la modificación de las interacciones RNA-proteína pueden permitir una atenuación o una actividad antiviral [22].

En la literatura existen reportes de proteínas del hospedero maíz que se encontraron 
interactuando con proteínas codificadas por SCMV. Por ejemplo las interacciones entre la elongina C y la proteína viral VPg [23], o la interacción entre la Ferredoxina-5 con la proteína viral HC-Pro [24]. Sin embargo la interacción de proteínas del hospedero con las regiones no traducidas ha sido menos estudiada, a pesar de la importante función de estas regiones en el proceso de traducción en virus, que no presentan una estructura caperuza (cap) 7-metilguanosina (m7GpppG) en el extremo 5' como es el caso de los ARN mensajeros de eucariotas.

La mayoría de los virus de ARN han evolucionado diversos elementos de ARN en las regiones no traducidas 3' y 5' para reclutar el complejo ribosomal e iniciar la traducción en el codón AUG próximo al extremo 5' [25]. En los potyvirus, como SCMV, en el extremo 5'UTR, en lugar de una estructura cap, se encuentra una proteína viral VPg unida covalentemente que remplaza la estructura cap, y el extremo 3'UTR está poliadelinado [26]. De acuerdo a los resultados de entrecruzamiento por luz ultravioleta, en este estudio se encontró que en el hospedante maíz existe por lo menos una proteína de aproximadamente $53 \mathrm{kDa}$, que posiblemente esté interactuando con la región 5' UTR del potyvirus SCMV.

Los resultados obtenidos al tratar el complejo ARN-proteína con concentraciones crecientes de solución salina, sugieren que esta proteína putativa de interacción forma complejos estables con los transcritos de la región 5' UTR de SCMV. Así mismo, la especificidad de la formación del complejo fue confirmada en ensayos de competencia utilizando ARN de transferencia como control. La formación de complejos estables y específicos, sugieren que la interacción del ARN de SCMV con la proteína de $53 \mathrm{kDa}$ podría desempeñar una función importante en la traducción de SCMV.

Dado que la región 5'proximal de los genomas de algunos virus de ARN contienen elementos que desempeñan funciones críticas en la traducción, se podría proponer de manera preliminar que la proteína de $53 \mathrm{kDa}$ que se encuentra interactuando con esta región, posiblemente cumpla un papel como proteína auxiliar en la trascripción o traducción del virus por interacción directa con la región, o sirviendo como puente entre la región 5' UTR y la 3' UTR, ya que el sistema de transcripción y traducción de los virus de ARN con estructura tipo cap en el extremo 5 'del genoma forman un puente con el otro extremo circularizando su genoma [27]. Se requiere de estudios complementarios para confirmar lo encontrado en este estudio.

\section{Conclusiones}

Se encontró evidencia preliminar de que una proteína de aproximadamente $53 \mathrm{kDa}$ del hospedante maíz puede estar interactuando de manera específica y estable con la región 5'UTR del virus del mosaico de la caña de azúcar, la cual al interactuar con esta región del genoma viral sugiere que podría desempeñar una función en la traducción del genoma viral. Sin embargo, es necesario realizar análisis posteriores que permitan identificar la naturaleza de la proteína. El conocimiento y comprensión más detallado de las funciones de las proteínas de unión al ARN del hospedero requeridas para la replicación viral pueden ayudar al desarrollo de estrategas antivirales novedosas [18].

\section{Agradecimientos}

El autor expresa su agradecimiento a la Dra. L. Gutiérrez del Cinvestav México por la capacitación en técnicas de entrecruzamiento con luz ultra violeta y técnicas radiactivas.

\section{Referencias}

[1] D.D. Shukla, M. Tosic, J.M. Jilka, R. Ford, W. Toler, and A. Langham, "Taxonomy of potyvirus infecting maize, sorhum, and sugarcane in Australia and the united States as 
No. 1

Enero - Junio 2017 ISSN 0122-820X E-ISSN 2422-5053 PP: 103-111 determined by reactivities of polyclonal antibodies directed towards virusspecific N-termini of coat proteins", Phytopatology, vol. 79, pp. 223-229, 1989.

[2] P. Ahlquist, A.O. Noueiry, W.M. Lee, D.B. Kushner and B.T. Dye, "Host factors in positive-strand RNA virus genome replication", $J$ Virol, vol. 77, pp. 8181-6, Aug 2003.

[3] S.U. Huh and K.H. Paek, "Plant RNA binding proteins for control of RNA virus infection," Front Physiol, vol. 4, p. 397, 2013.

[4] J.C. Carrington, K.D. Kasschau, S.K. Mahajan and M.C. Schaad, "Cell-toCell and Long-Distance Transport of Viruses in Plants," Plant Cell, vol. 8, pp. 1669-1681, Oct 1996.

[5] J.L. Riechmann, M.T. Cervera and J.A. Garcia, "Processing of the plum pox virus polyprotein at the $\mathrm{P} 3-6 \mathrm{~K} 1$ junction is not required for virus viability," J Gen Virol, vol. 76 ( Pt 4), pp. 951-6, Apr 1995.

[6] S. Urcuqui-Inchima, J. Walter, G. Drugeon, S. German-Retana, A. L. Haenni, T. Candresse, et al, "Potyvirus helper component-proteinase selfinteraction in the yeast two-hybrid system and delineation of the interaction domain involved," Virology, vol. 258, pp. 95-9, May 251999.

[7] B.C. Kang, I. Yeam, J.D. Frantz, J.F. Murphy and M.M. Jahn, "The pvr1 locus in Capsicum encodes a translation initiation factor eIF4E that interacts with Tobacco etch virus VPg," Plant $J$, vol. 42, pp. 392-405, May 2005.

[8] K. Thivierge, V. Nicaise, P.J. Dufresne, S. Cotton, J.F. Laliberte, O.Le Gall, et al, "Plant virus RNAs. Coordinated recruitment of conserved host functions by $(+)$ ssRNA viruses during early infection events," Plant Physiol, vol. 138, pp. 1822-7, Aug 2005.

[9] P.D. Nagy and J. Pogany, "The dependence of viral RNA replication on co-opted host factors," Nat Rev Microbiol, vol. 10, pp. 137-49, Dec 19 2011.

[10] D. Guo, M.L. Rajamaki, M. Saarma and J.P. Valkonen, "Towards a protein interaction map of potyviruses: protein interaction matrixes of two potyviruses based on the yeast two-hybrid system," $J$ Gen Virol, vol. 82, pp. 935-9, Apr 2001.

[11] C. Robaglia and C. Caranta, "Translation initiation factors: a weak link in plant RNA virus infection," Trends Plant Sci, vol. 11, pp. 40-5, Jan 2006.

[12] J. Diaz-Pendon, V. Truniger, C. Nieto, J. Garcia-Mas, A. Bendahmane and M. A. Aranda, "Advances in understanding recessive resistance to plant viruses," Mol Plant Pathol, vol. 5, pp. 223-233, 2004.

[13] F. Revers, O. Le Gall, T. Candresse, and A. Maule, "New Advances in Understanding the Molecular Biology of Plant/Potyvirus Interactions," MPMI, vol. 12, pp. 367-376, 1999.

[14] J.C. Carrington, P.E. Jensen and M.C. Schaad, "Genetic evidence for an essential role for potyvirus CI protein in cell-to-cell movement," Plant $J$, vol. 14, pp. 393-400, May 1998.

[15] V.V. Dolja, R. Haldeman-Cahill, A.E. Montgomery, K.A. Vandenbosch and J.C. Carrington, "Capsid protein determinants involved in cell-to-cell and long distance movement of tobacco 
etch potyvirus," Virology, vol. 206, pp. 1007-16, Feb 11995.

[16] K.D. Kasschau, S. Cronin and J.C. Carrington, "Genome amplification and long-distance movement functions associated with the central domain of tobacco etch potyvirus helper component-proteinase," Virology, vol. 228, pp. 251-62, Feb 171997.

[17] S. Vashist, L. Urena, Y. Chaudhry and I. Goodfellow, "Identification of RNAprotein interaction networks involved in the norovirus life cycle," J Virol, vol. 86, pp. 11977-90, Nov 2012.

[18] Z. Li and P.D. Nagy, "Diverse roles of host RNA binding proteins in RNA virus replication," RNA Biol, vol. 8, pp. 305-15, Mar-Apr 2011.

[19] A.L. Gutierrez-Escolano, Z.U. Brito, R.M. del Angel and X. Jiang, "Interaction of cellular proteins with the 5 ' end of Norwalk virus genomic RNA," J Virol, vol. 74, pp. 8558-62, Sep 2000.

[20] M. Caputi and A.M. Zahler, "Determination of the RNA binding specificity of the heterogeneous nuclear ribonucleoprotein (hnRNP) H/H'/ F/2H9 family," J Biol Chem, vol. 276, pp. 43850-9, Nov 232001.

[21] G.P. Patel, S. Ma and J. Bag, "The autoregulatory translational control element of poly(A)-binding protein mRNA forms a heteromeric ribonucleoprotein complex," Nucleic Acids Res, vol. 33, pp. 7074-89, 2005.

[22] V. Fontanes, S. Raychaudhuri and A. Dasgupta, "A cell-permeable peptide inhibits hepatitis $\mathrm{C}$ virus replication by sequestering IRES transacting factors," Virology, vol. 394, pp. 82-90, Nov 10 2009.
[23] M. Zhu, Y. Chen, X.S. Ding, S.L. Webb, T. Zhou, R.S. Nelson, et al, "Maize Elongin $\mathrm{C}$ interacts with the viral genome-linked protein, $\mathrm{VPg}$, of Sugarcane mosaic virus and facilitates virus infection," New Phytol, vol. 203, pp. 1291-304, Sep 2014.

[24] Y.Q. Cheng, Z.M. Liu, J. Xu, T. Zhou, M. Wang, Y.T. Chen, et al, "HC-Pro protein of sugar cane mosaic virus interacts specifically with maize ferredoxin-5 in vitro and in planta," $J$ Gen Virol, vol. 89, pp. 2046-54, Aug 2008.

[25] J. Zhang, R. Roberts and A.M. Rakotondrafara, "The role of the 5' untranslated regions of Potyviridae in translation," Virus Res, vol. 206, pp. 7481, Aug 32015.

[26] M.J. Adams, J.F. Antoniw and F. Beaudoin, "Overview and analysis of the polyprotein cleavage sites in the family Potyviridae," Mol Plant Pathol, vol. 6, pp. 471-87, Jul 12005.

[27] T.W. Dreher and W.A. Miller, "Translational control in positive strand RNA plant viruses," Virology, vol. 344, pp. 185-97, Jan 52006. 